Vol. 22, $n^{\circ} 1 \mid 2018$

Varia

\title{
Drew D. Gray, Crime, Police and Punishment in
}

England, 1660-1914

London, Bloomsbury Academic, 2016, xii + 393 p., ISBN 978-1-4411-1765-6

(Paperback)

James Sharpe

\section{(2) OpenEdition}

Journals

Electronic version

URL: http://journals.openedition.org/chs/2204

DOI: $10.4000 /$ chs.2204

ISSN: 1663-4837

Publisher

Librairie Droz

\section{Printed version}

Date of publication: 31 October 2018

Number of pages: 145-146

ISSN: 1422-0857

\section{Electronic reference}

James Sharpe, "Drew D. Gray, Crime, Police and Punishment in England, 1660-1914", Crime, Histoire \& Sociétés / Crime, History \& Societies [Online], Vol. 22, n¹ | 2018, Online since 31 December 2018, connection on 13 January 2021. URL: http://journals.openedition.org/chs/2204 ; DOI: https://doi.org/ $10.4000 /$ chs. 2204

This text was automatically generated on 13 January 2021.

(c) Droz 


\section{Drew D. Gray, Crime, Police and Punishment in England, 1660-1914}

London, Bloomsbury Academic, 2016, xii + 393 p., ISBN 978-1-4411-1765-6 (Paperback)

James Sharpe

\section{REFERENCES}

Drew D. Gray, Crime, Police and Punishment in England, 1660-1914, London, Bloomsbury Academic, 2016, xii + 393 p., ISBN 978-1-4411-1765-6 (Paperback)

Drew D. Gray has an established and growing reputation as a researcher into the English criminal justice system of the eighteenth and nineteenth centuries, and it is entirely appropriate that he should turn his hand to writing an overview book on this subject, broadly defined. Writing a book over the timespan envisaged here - joining, as it were the long eighteenth and the long nineteenth centuries - is ambitious, but any risks thus involved are fully justified. This is a very effective overview, and the author is fully justified in his desire to trace later developments, where appropriate, to their late seventeenth-century roots. The book is clearly mainly intended for students (there is an associated website containing seminar exercises and a more extensive bibliography than that offered in the book itself) but non-specialist academics wanting a modern and balanced introduction to the subject will also find this book an extremely effective introduction.

2 The book is divided into two main sections, "Key Themes in the History of Crime" and "The Evolution and Development of the English Criminal Justice System". Between them, these two sections cover most of the areas on which research has been carried out by historians of crime and criminal justice in England over the relevant timespan. Thus in the first section, after an introductory chapter on methods, themes and debates in the history of crime and punishment, we find chapters on media and crime, on violence, focussing on the decline of homicide and the apparent growing intolerance 
towards assault, the nature of property crime, and the causes of property crime. There is also a chapter gender on crime focussing on the woman as victim, another chapter on gender and crime, concentrating of women as perpetrators of crime, and a very useful chapter on juvenile crime and the emergence of the concept of the young offender.

3 The second section, on the evolution and development of the English criminal justice system, provides both overviews of familiar subjects, such as the transition of policing from the old style parish constable to the post 1829 professional police. But it also offers introductions to less familiar, and in some respects under-researched, topics, such as the transition "from parlour to police court", delineating the role of the old style justice of the peace and how that office developed into the modern magistrate. The third chapter in this section is devoted the changing nature of prosecution in English courts (characterised as "removing the victim"), which is then followed by two chapters on punishment, delineated chronologically. The first deals with the changing nature of the punishment over the long eighteenth century, treatment of this theme being focussed on the decline and fall of the "Bloody Code", while the second analyses the rise and fall of incarceration. The book is rounded off with a short chapter containing conclusions and suggestions for further research.

4 Inevitably, there are grounds for criticism. Some of these are fairly minor: I am unconvinced that "we know all we need to know about highwaymen" (p. 328) - surely the topic is calling out for an in-depth academic study which takes us beyond the criminal biographies of highway robbers that are contained in pamphlets. And, although this is perhaps unfair criticism given the already broad chronological span of the book, Gray is clearly not at his best when looking at the early modern end of his timespan. Few experts would now see the decline of witch-trials as simply the result of the onward march of rationality (p. 15), Gray's comments on early modern evaluations of criminal behaviour in terms of the contemporary religious framework needed rather more rigour (p.19), and his comments on pre-modern childhood are sadly outdated (p. 179). More seriously, his two chapters on gender might easily lead the less wary student thinking that gender is purely about women (one notes the index entry, "women, See gender") - more should have been made of the links between masculinity and crime, notably via violence (which Gray correctly identifies as being largely a male activity) and gangs and criminal subcultures. Likewise the chapter on media and crime might perhaps have said rather more about everyday media (pamphlets, ballads, and provincial newspapers) and a little less on high profile cases. There are also, perhaps inevitably for a book of this size, a few deficiencies in proofreading: one suspects that it was not depictions of "the dandy highway" that Gray was trying to draw our attention to in his penultimate paragraph.

5 The criticisms must not, however, be allowed to detract from the immense value of Crime, Policing and Punishment in England, 1660-1914. Gray deploys an enviable knowledge of his field, and is equally at home with established approaches and debates and with more recent developments, research into some of which, of course, he has pioneered himself. This grasp of his subject enables him to lead the reader through contentious areas with a deft hand, and leave him or her better informed and aware of how views on the issues at hand have developed. Two chapters where this expert handling of arguments is deployed at its best are those dealing respectively with the emergence of professional policing and the rise and fall of incarceration. In the former, for example, 
the old triumphalist neo-whig interpretation of police history, which is probably still widely accepted by the general reader and most undergraduates, is successfully challenged, with references to Joan R. Kent's work on the early modern parish constable, to Bob Storch's classic "Plague of Blue Locusts" article of 1975, and more recent work by Clive Emsley and Chris Williams. Here as elsewhere, we are presented with a balanced view of the arguments involved, how they fit with both the developing historiography around the subject and how and why the issue (in this case policing) achieved historical importance. And in the chapter on incarceration Gray is able to attain another of his objectives, demonstrating how the history of crime and punishment might occasionally illuminate the absurdities of some of our current debates on the subject.

6 Overall this is a welcome and successful book which will rapidly establish itself as the major work of synthesis on and introduction to crime, the law enforcement system, and punishment in England over the period it covers.

\section{AUTHORS}

\section{JAMES SHARPE}

Department of History

University of York, UK

jim.sharpe[at]york.ac.uk 